Article

\title{
Comparative Inclusion: What Spanish Higher Education Teachers Assert
}

\author{
Amparo Pérez-Carbonell ${ }^{1, *}$, Genoveva Ramos-Santana ${ }^{1}$ and María-Jesús Martínez-Usarralde ${ }^{2}$ \\ ${ }^{1}$ Department of Research Methods and Educational Diagnosis, Faculty of Philosophy and Education Sciences, Spain; \\ E-Mails: amparo.perez@uv.es (A.P.-C.), genoveva.ramos@uv.es (G.R.-S.) \\ ${ }^{2}$ Department of Comparative Education and Education History, Faculty of Philosophy and Education Sciences, Spain; \\ E-Mail: m.jesus.martinez@uv.es \\ * Corresponding author
}

Submitted: 20 January 2021 | Accepted: 4 June 2021 | Published: 21 July 2021

\begin{abstract}
From a critical comparative perspective (far from more naive and resolute trends) this study delves into the problematisation that comes with recognising comparative education as 'the science of the difference' (Nóvoa, 2018). Despite the cementation of discursive, regulatory, and normative governance, of a new higher education regime (Zapp \& Ramirez, 2019) revealing the growing isomorphism in the global political and educational discourse of academics, some idiosyncratic characteristics can be detected as a result of the policy implemented in each context. The aim of this article is to compare the beliefs and attitudes of professors from seven Spanish universities regarding diversity, as well as the level of inclusion in higher education, by means of an exploratory, descriptive, and comparative survey. A total of 977 educators participated in a purposive sampling. Descriptive techniques, contrasting differences and comparing proportions allowed us to detect that, although there are no major differences between the teachers' beliefs and attitudes, some of the minor ones are still worth highlighting. Some of these are the commitment to incorporate diversity in methodologies and teaching resources, in their attempt to meet the needs of diverse people, or the way they perceived personal or institutional commitment to diversity. In conclusion, it is necessary to take a stance on diversity and inclusion that supports the need to stop and reflect on the richness they can provide, from a comparative position and constantly distancing ourselves (Kim, 2020) from today's university system.
\end{abstract}

\section{Keywords}

comparative education; diversity; higher education; inclusion; Spain; teachers; teachers' attitudes and values

\section{Issue}

This article is part of the issue "Inclusive Universities in a Globalized World" edited by Liudvika Leišyte (TU Dortmund, Germany), Rosemary Deem (Royal Holloway, UK) and Charikleia Tzanakou (Oxford Brookes University, UK).

(C) 2021 by the authors; licensee Cogitatio (Lisbon, Portugal). This article is licensed under a Creative Commons Attribution 4.0 International License (CC BY).

\section{Introduction}

In today's global learning scenarios, educational inclusion is an issue of increasing relevance, given that current times call for a new ethical revolution, because "we need freedom in education and its associated responsibilities" (Escotet, 2020, p. 74). Based on this evidence, higher education institutions constitute key sites (Powell, 2020) and even contestation environments (Allais et al., 2020) that can transfigure inclusion into comprehensive and effective organisational, management, and extension policies.
This study wants to provide an additional contribution to a promising and trending line of research which Schuelka and Lapham (2018, p. 38) called 'comparative and international inclusive education,' one that recognises that there is no single answer to how to compare inclusive education. To do this, we want to found our research on critical comparative education, which tries to move away from the solutionist drift of current politics and recognise the urgency of a science of the difference (Nóvoa, 2018). A science to evince the idiosyncratic characteristics of each policy in relation with the 
establishment, in the shape of a global discursive governance that reveals a new higher education regime (Zapp \& Ramirez, 2019), largely promoted by international organisations. Besides inclusion, other critical and intersectional readings can be done from paradigms such as colonialism, humanism, modernism, conventionalism (Whitburn et al., 2017), transculturality (Thomsen et al., 2020), feminism (Djavadghazaryans, 2020; Tzavara \& Wilczek, 2019), and human rights and social justice models (Khumalo, 2019). From these models, globalisation is paradoxically seen as a factor that causes more inequity in higher education (van Vught et al., 2018). In this sense, system diversity constitutes an essential condition that makes it possible for education to play its meritocratic role in society and counter the negative effects of globalisation. This, therefore, calls into question how higher education institution s have become hybrid organisations that subordinate morals and educational imperatives to economic obligations, including business interests, competition, innovation, flexibility, and productivity (Matthews et al., 2019) instead of focusing on training students with a critical and civic mind and according to cultural, social, and economic demands (Dias \& Soares, 2018).

Based on these considerations, the general aim of this study is to explore the beliefs and attitudes of the teaching staff of different universities regarding diversity and their degree of inclusion in the context of higher education. It attempts to do so coming from comparative education. Based on institutionalism and New Institutionalism (Meyer \& Powell, 2020), this line of research focuses on estrangement (Kim, 2020; Nóvoa, 2018) as a process of enquiry, visible in the results of our research.

\section{General Framework}

\subsection{Higher Education, Inclusion, and University Faculty}

Inclusive education has focused on political, social, and cultural processes to the detriment of the educational systems themselves, under the aspiration to become an 'education for everyone' (Black-Hawkins, 2017). In this regard, the work of international organisations has contributed to strategically formulate political orthodoxy in relation to global inclusion (Martínez-Usarralde, 2021), as is the case with UNESCO, the World Bank, or the $\mathrm{OECD}$, integrated in agendas that demand increasingly global standards and focus on specific goals to improve the students' success. The Sustainable Development Goals (commonly known as the SDGs) also contribute to provide new opportunities to address the challenge of transnational inclusion (Cox, 2019). Under the motto "Leave No One Behind," the 2030 Agenda aims to ensure that all human beings can realise their potential with dignity and equality and in a healthy environment.

On the other hand, higher education has also embraced this principle, leading to an internationalisation that could be classified as isomorphic (Lingard et al.,
2013), as defined by the New Institutionalist current (Meyer \& Powell, 2020). From its heuristic potential to explain how institutions strive to emulate each other' best practices, this sociological-political theory scrutinizes the spaces in which the different social protagonists develop their practices. It also focuses on the study of institutions, from a methodological combination of both quantitative and qualitative perspectives (ethnographic, cross-cultural, historical, and comparative studies). In their attempt to gain legitimacy, universities tend to imitate the forms and structures of established institutions through a discursive, normative, and regulated governance for accreditation, standardization, recognition, and quality assurance. At the same time, and together with equity, it establishes inclusion as a priority in the political agenda, based on access, progress, participation, and fulfilment criteria. In addition, it integrates inclusion into policies, programs, curricula, methodologies, practices, innovation, evaluation, research, climate, culture, impact, projection, and transfer (Bayrak, 2020; Buenestado et al., 2019; Carballo et al., 2019; Sengupta, et al., 2019), all of them indicators of institutional assessment. The prolific discourse on the social responsibility of universities, through the growth of fields such as education for sustainable development and global citizenship and the development of civic and community capacities, among others, also contributes to inclusion, because it highlights the aspiration to create a more inclusive, responsible, and holistic higher education sector (Symaco \& Tee, 2018), although it is also critically read as yet another contradiction, compared to a competitive university model. Together with all that, we can currently discuss aspirations to inclusive leadership (Blessinger et al., 2018) or inclusive excellence resulting from current university policies that confirm and extend good practices and make them more visible, while also measuring parameters that constitute elements of institutional analysis.

Within this framework, university educators and their regard of inclusion educational policies represent a promising line of research, although we must note that this sort of studies are still scarce. The present project aspires to contribute to them. In line with this trend, several fronts are detected in current research. On the one hand, there is a line focusing on learning more about the beliefs, attitudes, and values of educators in relation to this universal principle (Carballo et al., 2019; Emmers et al., 2019; Martins et al., 2018; Moberg et al., 2020). On the other, there are studies evidencing the need to better train this group of professionals in diversity and educational inclusion (Benet, 2020; Collins et al., 2019; Sanahuja et al., 2020). And there is a third research trend analyzing the adequacy and relevance of teaching methodologies with regards to the presence of inclusion in daily classroom practice (Sharma \& Mullick, 2020), from the consideration of inclusive pedagogies (Stentiford \& Koutsouris, 2020), peer-review processes (Sengupta et al., 2019), students as collaborators 
(Matthews et al., 2019), or service learning (Chambers \& Lavery, 2018; Ramia \& Díaz, 2019).

The latter includes many studies. Lawrie et al. (2017) reviewed 53 papers connected to inclusive teaching and learning published since 2010 and concluded that the literature considered in the study used the term 'inclusive' to discuss pedagogies that understand the diversity of needs of the students and do not create obstacles for particular students or groups. Rubio (2017, p. 213) revealed in her study the critical self-reflection of academics regarding their own educational practices, related to integration, rather than inclusion. Orozco and Moriña (2020) argued that the methodological strategies related to the needs of students should be compulsory for all members of the staff. Insisting on the latter, Carballo et al. (2019) analyzed inclusive teacher training programs and how they allow professionals to develop inclusive strategies from a practical point of view, integrating Universal Design for Learning (commonly referred to as UDL) into them. Melero et al. (2019) also discussed this topic. For their part, Nind and Lewthwaite (2018) recognize the pedagogical role of educators to send the students along inclusive paths, which is a core element in the teachers' development of their own methodological capacities. Ryder et al. (2016) maintain that faculty members are influential not only because of how they teach, but also in relation to the climate they create for learning, exploring the relationship between students' perceptions of the learning environment and their openness to diversity and change. Moliner et al. (2020) analyzed inclusion-related information and interaction used by university teachers and researchers, aiming to take advantage of this knowledge and disseminate their practices.

In the Spanish context, educational inclusion policies have traditionally been developed in schools, rather than in the university environment (Orozco \& Moriña, 2020), so, at present, there is still a long way to go (Melero et al., 2019), both in research and in practice. Based on this, Spanish universities have been following the recommendations from their regulatory framework, although the debate on diversity in universities has been initiated by leaders themselves and has barely been broached in Spain (García-Cano et al., 2021). From an institutionalization approach and with a firmly rooted commitment to attention to student diversity (Carballo et al., 2019), Spanish universities have mainly focused until very recently on providing attention to disability with support services and units, which currently constitute a notable idiosyncratic line in these institutions (Morgado et al., 2017; Moriña, 2017). This is evidenced by the research developed to test the advances of the social model of disability (Melero et al., 2018), which has been the starting point to measure evaluation and innovation processes, the teaching atmosphere, or the strategies and methodology of the teaching staff (Carballo et al., 2019; Morgado et al., 2017; Moriña \& Carballo, 2017). Today, state initiatives in the field of inclusion are varied, although there is still no global Spanish diagnosis, nor have sufficient studies been carried out to establish which model of inclusion is being used as a starting point. Although research insists on the importance of providing better training in inclusive strategies for the Spanish university teaching staff (Benet, 2020; Moliner et al., 2020), as well as on the strategic role of university leaders (García-Cano et al., 2021), the actions they carry out, examined in light of the few studies based on the publication of plans, programs, guides, and specific qualifications (Álvarez et al., 2021), are mostly aimed at accessibility in spaces and buildings, curricular adaptation, disability awareness policies, welcoming and guidance processes for students, and, to a lesser extent, specific counselling for other diverse groups or the implementation of plans or programs to cater for diversity. All of the above is evidence of the existence of a dual asymmetric model based more on productive rankings than on the rhetoric of social justice (Álvarez et al., 2021).

Thus, based on these educational challenges, this study proposes the following research questions: Are there idiosyncratic features regarding the beliefs and attitudes of the teaching staff of the different universities towards diversity and their degree of inclusion? In what areas and dimensions? If that is not the case, is there a certain degree of homogenization as a result of the socio-political and educational influences of global governance, which impact university faculty's considerations regarding educational inclusion?

\section{Methodology}

The present research is a first approach to address this subject: the attitudes, beliefs, and practices of Spanish university lecturers regarding the attention to diversity. To this end, we present an ex post facto, exploratory, quantitative, non-experimental, and crosssectional research design. The coincidences and divergences in the beliefs and attitudes of higher education faculty members regarding diversity and inclusion are explored based on a descriptive-comparative survey. From a research approach fueling the trend on comparative and international inclusive education discussed by Schuelka and Lapham (2018), this study has reconsidered both the actions and the underlying mindsets. Ethics has also been considered as a cross-cutting element in all research phases, which were informed by three basic ethical principles: consent, care, and honesty (Wood \& Smith, 2018).

\subsection{Participants}

Given the exploratory nature of this research, a purposive sampling was chosen, with voluntary subjects from the teaching staff of the universities collaborating in the InclUni Project. Seven public universities took part in the survey. In order to collect the teaching staff's perception, an online questionnaire was designed. This method 
offers important advantages (the possibility of accessing a large pool of respondents, increased speed and lower cost in the collection of information) but also disadvantages such as the low response rate due to the high rate of abandonment or the fact that often not all the questions in the questionnaire are completely filled in. These aspects led to a total 977 respondent educators (see Table 1). Within this group, $51,90 \%$ are women and $48,1 \%$ are men, with an average age of 47 years; $81,90 \%$ are permanent staff and have 15 years seniority at their institution. It should be stressed that, while this is not a probabilistic sample, the characteristics of the group of teachers in the sample (sex, age, professional category, and seniority) are similar to those of the reference population.

\subsection{Instrumentation}

The information collection procedure was common for all universities during the 2018-2019 academic year. It was made using an ad hoc online questionnaire (LimeSurvey). The elements were extracted from the following references: American Association of Colleges and Universities (2015), Baker et al. (2012), Ford Foundation (1999), and NERCHE (2016). The initial questionnaire was submitted to several experts which, according to quantitative and qualitative criteria, assessed the representativeness, relevance, understandability, and clarity of its content (items and dimensions). Evidence of the validity of the questionnaire's internal structure was then collected. An exploratory factor analysis (EFA) was carried out using the principal components extraction method, with Varimax rotation and Kaiser normalization. Confirmatory factor analysis (CFA) was used to determine the appropriateness of the scale (Ramos et al., 2021). Analyses carried out with different subsamples and with factor loadings equal to or greater than 0.40 . The questionnaire validity was tested using Cronbach's Alpha method. The total Alpha value (.89) indicates a high correlation and a high level of stability in responses. The resulting document consists of 19 items and five dimensions whose answers are measured using a Likert ordinal scale, from strongly disagree (1) to strongly agree (5).

\subsection{Data Analysis}

The statistical analyses of this study were carried out using the Statistical Package for the Social Sciences v. 24. First of all, we set out to find out the subjective opinions of the teaching staff by carrying out a series of basic descriptive statistics. Secondly, and respecting the measurement level of the variables, as well as the lack of variance of the items, the answers given by the teachers were dichotomized (1-2) to perform the Chi-square $\left(X^{2}\right)$ analysis with subsequent contrasts based on the z-test for difference in proportions.

\section{Results}

Data exploration allowed us to describe the collective perception of the faculty of the 7 universities participating in the study (see Table 2).

To answer whether or not there are idiosyncratic characteristics in teachers' beliefs and attitudes towards diversity and their degree of inclusion in the different universities, this study uses Pearson's Chi-square test, which allows us to verify that the hypothesis of independence between the variables studied in seven items of the analyzed set is not supported. In other words, there are seven items in which the association between belonging to a specific university and the evaluation provided by the teaching staff is confirmed.

In item 6-specific subjects focusing on the role of women and minorities in the development of societies should be integrated into university curricula-the association seems to be explained by the higher proportion of agree or strongly agree answers given by the teaching staff of the Universidad Pablo de Olavide, as opposed to the teaching staff of other Universities (Sevilla, Córdoba, Complutense de Madrid, Cádiz, and València), where the highest proportion corresponds to strongly disagree, disagree or neither disagree nor agree answers (see Table 3).

From our initial research approach, which aims to stand on the abovementioned attitude of initial estrangement and questioning, and as additional information, when examining this association we consider that the identification characteristics of the staff involved in this difference can enrich this study and illuminate the

Table 1. Participating universities.

\begin{tabular}{|c|c|c|c|c|c|c|}
\hline \multicolumn{3}{|c|}{ University } & \multirow{2}{*}{$\frac{\text { Frequency }}{51}$} & \multirow{2}{*}{$\frac{\text { Percentage }}{5,4 \%}$} & \multirow{2}{*}{$\begin{array}{c}\text { Established } \\
1997\end{array}$} & \multirow{2}{*}{$\frac{\text { Website }}{\text { www.upo.es }}$} \\
\hline 1 & Universidad de Pablo de Olavide & UPO & & & & \\
\hline 2 & Universidad de Sevilla & US & 118 & $12,4 \%$ & 1505 & www.us.es \\
\hline 3 & Universidad de Córdoba & UCO & 105 & $11,1 \%$ & 1972 & www.uco.es \\
\hline 4 & Universidad Complutense de Madrid & UCM & 444 & $45,4 \%$ & 1293 & www.ucm.es \\
\hline 5 & Universidad de Cádiz & UCA & 59 & $6,2 \%$ & 1979 & www.uca.es \\
\hline 6 & Universidad Nacional a Distancia & UNED & 52 & $5,5 \%$ & 1972 & www.uned.es \\
\hline 7 & Universitat de València & UV & 101 & $10,7 \%$ & 1499 & www.uv.es \\
\hline \multicolumn{3}{|c|}{ Total } & 977 & $100 \%$ & & \\
\hline
\end{tabular}


Table 2. Descriptive statistics.

\begin{tabular}{|c|c|c|c|c|c|}
\hline Concept of diversity dimension & $\bar{x}$ & $X m$ & $S$ & As & K \\
\hline $\begin{array}{l}\text { 1. The concept of diversity means different ethnicity, race, nationality, } \\
\text { or culture. }\end{array}$ & 3,97 & 4,0 & 1,18 & $-1,17$ &, 53 \\
\hline ... means people with different thoughts and ideas. & 3,91 & 4,0 & 1,24 & $-1,11$ & 25 \\
\hline ... means different level of education. & 3,16 & 3,0 & 1,45 &,- 23 & $-1,29$ \\
\hline Institutional diversity dimension & $\bar{x}$ & $X m$ & $S$ & As & $K$ \\
\hline $\begin{array}{l}\text { 4. Diversity, inclusion, and equity are essential in education and must be } \\
\text { addressed in any university institution. }\end{array}$ & 4,43 & 5,0 & ,94 & $-1,86$ & 3,17 \\
\hline $\begin{array}{l}\text {... are an institutional matter, but also an individual one, for each member } \\
\text { of the institution. }\end{array}$ & 4,45 & 5,0 & ,87 & $-2,05$ & 4,69 \\
\hline $\begin{array}{l}\text { 6. Specific subjects focusing on the role of women and minorities in the } \\
\text { development of societies should be integrated into university curricula. }\end{array}$ & 3,46 & 4,0 & 1,34 &,- 40 & $-1,01$ \\
\hline $\begin{array}{l}\text { 7. For universities, training people to succeed in a diverse world is as } \\
\text { important as providing them with technical or academic skills. }\end{array}$ & 4,08 & 4,0 & 1,05 & $-1,16$ & ,82 \\
\hline $\begin{array}{l}\text { 8. Universities should develop specific actions to address diversity in the } \\
\text { student body. }\end{array}$ & 4,12 & 4,0 & 1,05 & $-1,27$ & 1,15 \\
\hline Diverse teaching-learning practices dimension & $\bar{x}$ & $X m$ & $S$ & As & $K$ \\
\hline I provide support to help my students develop individualized learning plans. & 3,81 & 4,0 & 1,09 &,- 83 & 18 \\
\hline $\begin{array}{l}\text { 10. In my classes, I implement different teaching-learning methodologies to } \\
\text { cater for the diversity of the students. }\end{array}$ & 3,60 & 4,0 & 1,15 &,- 63 &,- 26 \\
\hline $\begin{array}{l}\text { 11. I offer resources to respond to the needs of students and to address the } \\
\text { development of inclusive education. }\end{array}$ & 3,65 & 4,0 & 1,14 &,- 76 &,- 04 \\
\hline $\begin{array}{l}\text { 12. In my subjects I include digital learning and/or cooperative activities to } \\
\text { promote learning for students with different needs. }\end{array}$ & 3,63 & 4,0 & 1,17 &,- 68 &,- 28 \\
\hline Research, training and teaching dimension & $\bar{x}$ & $X m$ & $s$ & As & $K$ \\
\hline $\begin{array}{l}\text { 13. I develop research that reflects, in form and/or content, my commitment } \\
\text { to diversity, inclusion, and equity as an added value to the research project. }\end{array}$ & 3,22 & 3,0 & 1,35 &,- 26 & $-1,05$ \\
\hline $\begin{array}{l}\text { 14. I incorporate into my research designs elements that favour the diversity, } \\
\text { inclusion, and equity of cultures, gender, and age, among others. }\end{array}$ & 3,20 & 3,0 & 1,34 &,- 29 & $-1,03$ \\
\hline $\begin{array}{l}\text { I design innovative teaching projects with an attention to gender, age, } \\
\text { culture, and religious diversity, among others. }\end{array}$ & 2,61 & 3,0 & 1,38 & ,27 & $-1,16$ \\
\hline I design teaching objectives focused on diversity, inclusion, and equity. & 3,34 & 3,0 & 1,31 &,- 41 &,- 87 \\
\hline Commitment of the leaders or governing bodies dimension & $\bar{x}$ & $X m$ & $S$ & As & $K$ \\
\hline $\begin{array}{l}\text { 17. In general, the management team of my university promotes diversity, } \\
\text { inclusion, and equity actions. }\end{array}$ & 3,61 & 4,0 & 98 &,- 51 & 15 \\
\hline $\begin{array}{l}\text { My university has a deep-rooted tradition in favor of diversity, inclusion, } \\
\text { and equity in curricular choices. }\end{array}$ & 3,33 & 3,0 & 99 &,- 27 & -15 \\
\hline ... offers training courses related to diversity, inclusion, and equity. & 3,64 & 4,0 & 1,03 &,- 51 & 13,- \\
\hline
\end{tabular}

Notes: $\bar{X}$ (Item average), $X m$ (Item median), $S$ (Standard Deviation), As (Asymmetry) and $K$ (kurtosis).

results. We refer to the fact that, when evaluating this item, the percentage of female lecturers responding from the Universidad Pablo de Olavide is higher than that of the rest of the universities - with the exception of the Universitat de València. In addition, the percentage of respondents who work as permanent lecturers was also higher, with a higher average age (with the exception of those at the Universitat de València), and $55,10 \%$ of them taught in Social Sciences.

As for item 10-In my classes, I implement different teaching-learning methodologies to cater for the diversity of the students-and item 12-In my subjects I include digital learning and/or cooperative activities to promote learning for students with different needsalthough there is a connection for both items, as shown by the Chi-square values and their associated probability, no sufficiently significant keys were found in subsequent comparisons of proportions to help us interpret which group of teachers favors the difference (see Table 4).

Continuing with the interpretation of the results, and looking at the proportions compared for item 14-l incorporate into my research designs elements that favor the 
Table 3. Chi-square and comparisons of proportions (item 6).

\begin{tabular}{|c|c|c|c|c|c|c|c|c|}
\hline \multicolumn{2}{|c|}{$\begin{array}{l}\text { Chi-square } X^{2} \\
\text { GI } \\
\text { Sig. asymptotic (bilateral) }\end{array}$} & \multicolumn{7}{|l|}{$\begin{array}{l}16,939^{a} \\
6 \\
, 010\end{array}$} \\
\hline & & $\begin{array}{l}\text { UPO } \\
\text { (A) }\end{array}$ & $\begin{array}{l}\text { US } \\
\text { (B) }\end{array}$ & $\begin{array}{l}\text { UCO } \\
\text { (C) }\end{array}$ & $\begin{array}{l}\text { UCM } \\
\text { (D) }\end{array}$ & $\begin{array}{l}\text { UCA } \\
\text { (E) }\end{array}$ & $\begin{array}{l}\text { UNED } \\
(\mathrm{F})\end{array}$ & $\begin{array}{l}\text { UV } \\
\text { (G) }\end{array}$ \\
\hline \multirow[b]{2}{*}{ Item 6} & $(1)$ & & $A(, 012)$ & $A(, 026)$ & $A(, 002)$ & $A(, 005)$ & & $A(, 041)$ \\
\hline & (2) & $\begin{array}{l}B(, 012) \\
C(, 026) \\
D(, 002) \\
E(, 005) \\
G(, 041)\end{array}$ & & & & & & \\
\hline
\end{tabular}

Notes: $\left({ }^{\mathrm{a}}\right) 0$ cells $(0,0 \%)$ have expected a count less than $5,(\mathrm{gl})$ degrees of freedom, (1) strongly disagree/disagree/neither disagree nor agree, (2) agree/strongly agree; significance level for capital letters: , 05.

Table 4. Chi-square (item 10 and item 12).

\begin{tabular}{llll}
\hline & Chi-square $\left(X^{2}\right)$ & Gl & Asymptotic significance (bilateral) \\
\hline item 10 & $15,384^{\text {a1 }}$ & 6 &, 017 \\
Item 12 & $12,774^{\text {a2 }}$ & 6 &, 047 \\
\hline
\end{tabular}

Note: $\left({ }^{\mathrm{a}}\right) 0$ cells $(0,0 \%)$ have expected a count less than $5,\left({ }^{\mathrm{a} 2}\right) 0$ cells $(0,0 \%)$ have expected a count less than 5 , (gl) degrees of freedom.

diversity, inclusion, and equity of cultures, gender, and age, among others - the association seems to be justified by the higher percentage of responses given by UCM lecturers, who tended more towards agree or strongly agree than those given by lecturers at the University of Valencia (see Table 5).

As substantial information and for reflection on the results regarding this item, we can add ideas such as the fact that the average age of the teaching staff at the Universitat de València is somewhat more advanced than that of the teaching staff at the Universidad Complutense de Madrid ( 50 and 47 years, respectively). that the teaching staff at the Universitat de València has more years of seniority (18 and 15 years, respectively), that it has a higher percentage of permanent teaching staff ( $88 \%$ and $76,2 \%$, respectively), and that the Universitat de València is the only university with a higher percentage of male lecturers than female lecturers.

As for item 15-I design innovative teaching projects with an attention to gender, age, culture, and religious diversity, among others - the justification for this association can be found in the proportions of responses of the teachers ("agree or strongly agree") at the Universidad Pablo de Olavide, which are higher than those of the teachers at the Universidad Complutense de Madrid (see Table 6).

Complementary information, which may help to extract other evidence and understand this association, could be found in the fact that teaching innovation projects in Spanish universities are promoted by their governing bodies. In this context, the management team of a young university, as is the case at the Universidad Pablo de Olavide, is more inclined to call for teaching innovation projects as an added value to its management policy. This is reflected in the higher frequency of applications from teaching staff and, consequently, the greater potential for incorporating attention to diversity in their projects.

The association found for item 18-My university has a deep-rooted tradition in favor of diversity, inclusion,

Table 5. Chi-square and comparisons of proportions (item 14).

\begin{tabular}{lllllllll}
\hline Chi-square $X^{2}$ & $20,457^{\mathrm{a}}$ & & & & & \\
GI & 6 & & & & & & \\
Sig. asymptotic (bilateral) &, 002 & & & & & & \\
\hline & UPO & US & UCO & UCM & UCA & UNED & UV \\
& (A) & (B) & (C) & (D) & (E) & (F) & (G) \\
\hline
\end{tabular}

Item 14

Notes: $\left({ }^{a}\right) 0$ cells $(0,0 \%)$ have expected a count less than $5,(\mathrm{gl})$ degrees of freedom, (1) strongly disagree/disagree/neither disagree nor agree, (2) agree/strongly agree; significance level for capital letters: ,05. 
Table 6. Chi-square and comparisons of proportions (item 15).

\begin{tabular}{|c|c|c|c|c|c|c|c|c|}
\hline \multirow{3}{*}{\multicolumn{2}{|c|}{$\begin{array}{l}\text { Chi-square } X^{2} \\
\text { GI } \\
\text { Sig. asymptotic (bilateral) }\end{array}$}} & \multirow{3}{*}{\multicolumn{7}{|c|}{$\begin{array}{l}14,897^{a} \\
6 \\
021\end{array}$}} \\
\hline & & & & & & & & \\
\hline & & & & & & & & \\
\hline & & $\begin{array}{l}\text { UPO } \\
(A)\end{array}$ & $\begin{array}{l}\text { US } \\
\text { (B) }\end{array}$ & $\begin{array}{l}\text { UCO } \\
\text { (C) }\end{array}$ & $\begin{array}{l}\text { UCM } \\
\text { (D) }\end{array}$ & $\begin{array}{l}\text { UCA } \\
\text { (E) }\end{array}$ & $\begin{array}{l}\text { UNED } \\
\text { (F) }\end{array}$ & $\begin{array}{l}\text { UV } \\
\text { (G) }\end{array}$ \\
\hline \multirow{2}{*}{ Item 15} & (1) & \multicolumn{7}{|c|}{$A(, 012)$} \\
\hline & (2) & \multicolumn{7}{|c|}{$D(, 012)$} \\
\hline
\end{tabular}

Notes: $\left({ }^{\mathrm{a}}\right) 0$ cells $(0,0 \%)$ have expected a count less than 5 , (gl) degrees of freedom, (1) strongly disagree/disagree/neither disagree nor agree, (2) agree/strongly agree; significance level for capital letters: , 05.

and equity in curricular choices-seems justified by the higher proportion of UNED teachers who answered agree or strongly agree, compared to teachers at other Universities (Seville, Cordoba, and Complutense; see Table 7).

From the line of research that has guided us, where estrangement from the results assumes a fundamental role in their interpretation, we would like to explain the associations found in this item by pointing out that the UNED is the only distance-learning university among the participants. This university is organized with associated centers in most Spanish cities, and it offers a wider range of courses than the rest of the universities, which leads to a wider curricular offer. Furthermore, due to its nature as a distance-learning university, it caters for a more diverse student body, which can undoubtedly lead its teaching staff to make greater curricular adaptations.

Finally, regarding item 19-My university offers training courses related to diversity, inclusion, and equitythe association seems to be explained by the higher proportion of teaching staff at the Universidad Complutense de Madrid who responded agree or strongly agree, compared to the teaching staff at the Universidad de Sevilla (see Table 8). We should note here that the general trend in the responses of the teaching staff of both universities on this item evidences the visibility that the UCM's governing team gives to attention to diversity. It is one of the universities with the widest range of diversity services in Spain, which shows its commitment to diver- sity and, therefore, to training its teaching staff in and for diversity.

Generally speaking, there is a general agreement among the faculty of the participating universities. More specifically, they agree in the way they understand diversity and its social value, as well as in the objectives and actions needed to address it. However, this level of agreement does not exist when assessing whether their universities' governing bodies show a long-standing inclination towards diversity or offer training courses in this area. They do not have the same perception either regarding the specific educational practices that they implement in their classrooms; nor do they have the same perception of the extent to which they incorporate diversity into their research projects.

The results reveal the need for further qualitative and quantitative research focused on analyzing the responses to the questionnaire. From a quantitative perspective, this will require submitting the questionnaire to a stratified random sample with affixation proportional to the size of the teaching population of each university and area of knowledge, together with collecting contextual indicators that show the specific actions of each university. This new procedure and data collection timing would allow us to carry out a comparative analysis (of both similarities or differences) and a relationship analysis (contextual indicators that promote actions to address diversity in universities) that can be extrapolated to other Spanish universities, including techniques such

Table 7. Chi-square and comparisons of proportions (item 18).

\begin{tabular}{|c|c|c|c|c|c|c|c|}
\hline $\begin{array}{l}\text { Chi-square } X^{2} \\
\text { GI } \\
\text { Sig. asymptotic (bilateral) }\end{array}$ & \multicolumn{7}{|l|}{$\begin{array}{l}22,270^{a} \\
6 \\
, 001\end{array}$} \\
\hline & $\begin{array}{l}\text { UPO } \\
\text { (A) }\end{array}$ & $\begin{array}{l}\text { US } \\
\text { (B) }\end{array}$ & $\begin{array}{l}\text { UCO } \\
\text { (C) }\end{array}$ & $\begin{array}{l}\text { UCM } \\
\text { (D) }\end{array}$ & $\begin{array}{l}\text { UCA } \\
\text { (E) }\end{array}$ & $\begin{array}{l}\text { UNED } \\
\text { (F) }\end{array}$ & $\begin{array}{l}\text { UV } \\
\text { (G) }\end{array}$ \\
\hline$(1)$ & & $F(, 000)$ & $F(, 018)$ & $F(, 002)$ & & & \\
\hline Item 18 & & & & & & $\begin{array}{l}\mathrm{B}(, 000) \\
\mathrm{C}(, 018) \\
\mathrm{D}(, 002)\end{array}$ & \\
\hline
\end{tabular}

Notes: $\left({ }^{a}\right) 0$ cells $(0,0 \%)$ have expected a count less than $5,(\mathrm{gl})$ degrees of freedom, (1) strongly disagree/disagree/neither disagree nor agree, (2) agree/strongly agree; significance level for capital letters: ,05. 
Table 8. Chi-square and comparisons of proportions (item 19).

\begin{tabular}{|c|c|c|c|c|c|c|c|c|}
\hline \multicolumn{2}{|c|}{$\begin{array}{l}\text { Chi-square } X^{2} \\
\text { GI } \\
\text { Sig. asymptotic (bilateral) }\end{array}$} & \multicolumn{7}{|c|}{$\begin{array}{l}17,984^{a} \\
6 \\
, 006\end{array}$} \\
\hline & & $\begin{array}{l}\text { UPO } \\
\text { (A) }\end{array}$ & $\begin{array}{l}\text { US } \\
\text { (B) }\end{array}$ & $\begin{array}{l}\text { UCO } \\
\text { (C) }\end{array}$ & $\begin{array}{l}\text { UCM } \\
\text { (D) }\end{array}$ & $\begin{array}{l}\text { UCA } \\
\text { (E) }\end{array}$ & $\begin{array}{l}\text { UNED } \\
\text { (F) }\end{array}$ & $\begin{array}{l}\text { UV } \\
\text { (G) }\end{array}$ \\
\hline \multirow{2}{*}{ Item 19} & (1) & & D (, & & & & & \\
\hline & $(2)$ & & & & $\mathrm{B}(, 00$ & & & \\
\hline
\end{tabular}

Notes: $\left({ }^{\mathrm{a}}\right) 0$ cells $(0,0 \%)$ have expected a count less than $5,(\mathrm{gl})$ degrees of freedom, (1) strongly disagree/disagree/neither disagree nor agree, (2) agree/strongly agree; significance level for capital letters: , 05.

as, for example, analysis of variance (ANOVA) and post hoc comparisons, regression analysis, or cluster analysis presenting teaching staff profiles according to their perception of 'attention to diversity' beliefs, attitudes, and practices. Likewise, and from a qualitative perspective, we urge experts to strive for a better understanding of these phenomena, by examining the macro, meso, and micro aspects of the educational context analyzed. In other words, an analysis of the complexity and diversity of elements involved in and affecting the institutionalization of attention to diversity, as well as individual perceptions of it.

\section{Discussion and Conclusions}

According to the objective and research questions guiding this investigation, in which we have explored and compared the beliefs and attitudes of the faculty of seven Spanish universities regarding diversity, we can draw some conclusions that aim to feed into the 'comparative, international, and inclusive education' line suggested by Schuelka and Lapham (2018).

Given the results obtained, and from a critical perspective encouraging us to take an attitude of 'estrangement' (which some comparatists maintain and we subscribe) through which, by distancing ourselves from the object of study, the interpretation opens up to new possibilities, limited not only to the naturalization of solutions (Nóvoa, 2018), we want to highlight the convergence of trends towards the homogenization of higher education policies which could be identified with the socio-political parameters of global governance (Zapp \& Ramirez, 2019). But it is also worth noting that there are divergences between some of the compared aspects which help to redirect attention to the underlying idiosyncrasy of each institution. From this perspective, stemming from the sociological new institutionalism that is the basis for our research, the aim is to disseminate the results internationally, thereby generating relevant knowledge so that other audiences and contexts interested in working from and for inclusive excellence can explore this research approach.

The limited number of participating universities, as well as the dissimilar size of their faculty, does not allow for conclusive results, but represents a possibility to explore, from the point of view of comparative education, the emergence of both analogous and idiosyncratic features of the participating universities.

As a result of the above-mentioned homogenization observed in the faculty regarding the analyzed dimensions, the isomorphism umbrella for some opinion trends is evident in their level of agreement, which, from a New Institutionalism perspective, can be seen as a unified understanding of inclusive education from standards of quality assurance, transparency, and mutual recognition. This can be observed in a triple tendency. The first aspect is marked both by the degree of agreement among the teaching staff on the concept of diversity and by their positive evaluation of proposals aimed at institutionalizing attention to diversity and involving the entire university community. The second, by the aforementioned indecision-neither agreement nor disagreement-in assessing their teaching-learning practices and the commitment of the people who lead their institutions. And the third, by their tendency towards disagreement when they evaluate the implementation of diversity in research, training, and teaching. These trends should be understood in the context of the universities' commitment to the institutionalization of diversity through inter-sectoral cooperation and strategic initiatives for impact and transparency.

However, this comparative micro-analysis has led to the emergence not only of isomorphisms, but also idiosyncratic characteristics. From a New Institutionalist perspective, these attributes translate into the need to also highlight the autonomy that these institutions should enjoy and, consequently, to shed light on the different ways university educators believe and act on diversity, which function as constructs derived from an estrangement that builds and even praises the science of difference. In connection to this analysis, the agreements that accentuate the concept of inclusion based on the idea of differences connected to ethnicity, race, nationality, and culture, compared to other collectives, confirm the results of previous studies (Krischler et al., 2019). This, in turn, endorses the critical inclusive vision that reaffirms the idea of "post-inclusive pedagogy" (Gibson, 2015, p. 876), evidencing power imbalances are a disadvantage in the management of educational groups. All of it crystallizes under the 
empowering, transcultural, and intersectional prism of equity and social and emancipatory justice (Thomsen et al., 2020; Walker, 2020). It follows a pedagogy that understands the moral concept of diversity in connection with social responsibility, focusing on learning opportunities (Martínez-Usarralde, 2021).

On the other hand, the differences derived from the participating teaching staff evaluations can be categorized into four significant findings whose evidence may be useful to those with university management and administration responsibilities. Firstly, the respondents understand University Social Responsibility as the institutional commitment from all impacts generated by the universities, but also from the personal conviction that implementing actions and methodologies is necessary, as is preparing students in a highly competent way (Carballo et al., 2019; Emmers et al., 2019; Orozco \& Moriña, 2020). Secondly, the university faculty are committed to these issues, which proves the need to incorporate different teaching-learning methodologies to cater for the diversity of the students, as stated in prior studies (Lawrie et al., 2017; Maringe \& Sing, 2014; Moriña \& Carballo, 2017; Nind \& Lewthwaite, 2018). Thirdly, we need to look for resources to meet student needs, including digital learning and/or cooperative activities to facilitate the learning of people with diverse needs (Rubio, 2017; Stentiford \& Koutsouris, 2020). And, finally, we have found out about the governing bodies' commitment and tradition regarding the principle of inclusion and attention to diversity (Collins et al., 2019; Wise et al., 2020).

Lastly, on a global, and even transversal sense, we must conclude that the process of interpretation of the data from this research has evidenced slight nuances that have outlined the similarities and idiosyncratic features of the analyzed universities, which are the result of differential beliefs and attitudes about diversity and inclusion that may be linked to some institutional and contextual factors (institution size and demographics, leadership and governance styles, economic and cultural characteristics of the environment, etc.), proving the need to keep shedding light on identity discourse of a critical, intersectional, and rights-based nature (Rubio, 2017) to complement the collective construction of an institutional educational inclusion discourse (Kermit \& Holiman, 2018). This study has therefore helped to continue nurturing an intellectual dialogue that assumes contradictions and refutes orthodoxy by adopting, based on comparison, a constant attitude of estrangement (Kim, 2020), together with ethics that make it impossible to silence discourses that can broaden real participation and thus feed the aforementioned social and emancipatory justice, far removed from the mechanisms of social control in today's university.

\section{Acknowledgments}

The study reported in this article was supported by the Spain's Ministry of Economy, Industry, and
Competitiveness, the State Research Agency, and the European Regional Development Fund (grant number EDU2017-82862-R).

\section{Conflict of Interests}

The authors declare no conflict of interests.

\section{References}

Allais, S., Unterhalter, E., Molebatsi, P., Posholi, L., \& Howell, C. (2020). Universities, the public good, and the SDG 4 vision. In A. Wulff (Ed.), Grading goal four (pp. 135-155). Brill Sense.

Álvarez, J. L., Hernández, C. M., González, H., Espino, L., \& Fernández, G. (2021). Exploring the status of diversity in policies and practices of Spanish universities. An asymmetric dual model. Heliyon, 7(3). https://doi. org/10.1016/j.heliyon.2021.e06450

American Association of Colleges and Universities. (2015). Committing to equity and inclusive excellence: A campus guide for self-study and planning. https://tinyurl.com/y8tq8bbz

Baker, K. Q., Boland, K., \& Nowik, C. M. (2012). Campus survey of faculty and student perceptions of persons with disabilities. Journal of Postsecondary Education and Disability, 25(4), 309-329.

Bayrak, T. (2020). A content analysis of top-ranked universities' mission statements from five global regions. International Journal of Educational Development, 72, 102-130. https://doi.org/10.1016/j.ijedudev. 2019.102130

Benet, A. (2020). Development of inclusive policies in higher education. Convergencia, 27, 1-31. https:// doi.org/10.29101/crcs.v27i82.11120

Black-Hawkins, K. (2017). Understanding inclusive pedagogy. In V. Plows \& B. Whitburn (Eds.), Inclusive education: Making sense of everyday practice (pp. 13-30). SensePublishers. https://doi.org/ 10.1007/978-94-6300-866-2_2

Blessinger, P., Hoffman, J., \& Makhanya, M. (2018). Introduction to perspectives on diverse student identities in higher education. In J. Hoffman, P. Blessinger, \& M. Makhanya (Eds.), Perspectives on diverse student identities in higher education: International perspectives on equity and inclusion (pp. 1-11). Emerald Publishing. https://doi.org/10.1108/S2055364120180000014002

Buenestado, M., Álvarez, J. L., González, H., \& Espino, L. (2019). Evaluate the institutionalization of the scope of diversity in the best universities in the world. PLOS ONE, 14(7), https://doi.org/10.1371/ journal.pone.0219525

Carballo, R., Morgado, B., \& Cortés-Vega, M. D. (2019). Transforming faculty conceptions of disability and inclusive education through a training programme. International Journal of Inclusive Education, 25(7). https://doi.org/10.1080/13603116.2019.1579874 
Chambers, D., \& Lavery, S. (2018). Introduction to service-learning and inclusive education. In S. Lavery, D. Chambers, \& G. Cain (Eds.), Service-learning: Enhancing inclusive education (pp. 3-19). Emerald Publishing. https://doi.org/10.1108/S1479-3636201 70000012001

Collins, A., Azmat, F., \& Rentschler, R. (2019). Bringing everyone on the same journey: Revisiting inclusion in higher education. Studies in Higher Education, 44(8). https://doi.org/10.1080/03075079.2018.1450852

Cox, C. (2019). The sustainable development goals and aging: Implications for social work. Journal of Human Rights and Social Work, 5. https://doi.org/10.1007/ s41134-019-00110-3

Dias, D., \& Soares, D. (2018). Civic learning outcomes: A step towards an inclusive higher education. International Journal of Inclusive Education, 22(4), 360-374. https://doi.org/10.1080/13603116.2017.1365956

Djavadghazaryans, A. (2020). Please don't gender me! Strategies for inclusive language instruction in a gender-diverse campus community. In R. Criser \& E. Malakaj (Eds.), Diversity and decolonization in German studies (pp. 269-287). Cham: Palgrave Macmillan.

Emmers, E., Baeyens, D., \& Petry, K. (2019). Attitudes and self-efficacy of teachers towards inclusion in higher education. European Journal of Special Needs Education, 35(2). https://doi.org/10.1080/08856257.2019. 1628337

Escotet, M. Á. (2020). Pandemics, leadership, and social ethics. Prospects, 1(49), 73-76. https://doi.org/ 10.1007/s11125-020-09472-3

Ford Foundation. (1999). The Ford Foundation campus diversity initiative survey of voters on diversity in education and an interview with Edgar Beckham. Equity \& Excellence in Education, 32(2), 17-23. http://dx. doi.org/10.1080/1066568990320204

García-Cano, M., Jiménez, A., \& Hinojosa, E. F. (2021). We're new to this. Diversity agendas in public Spanish universities according to their leaders. The Social Science Journal. Advance online publication. https:// doi.org/10.1080/03623319.2020.1859818

Gibson, S. (2015). When rights are not enough: What is? Moving towards new pedagogy for inclusive education within UK universities. International Journal of Inclusive Education, 19(8), 875-886. http://dx.doi. org/110.1080/13603116.2015.1015177

Kermit, P. S., \& Holiman, S. M. (2018). Inclusion in Norwegian higher education: Deaf students' experiences with lecturers. Social Inclusion, 6(4), 125-136. http:// dx.doi.org/10.17645/si.v6i4.1641

Khumalo, S. S. (2019). Rethinking the support programmes for the marginalised students in higher education through the lens of social justice. In J. Hoffman, J. Blessinger, \& M. Makhanya (Eds.), Strategies for fostering inclusive classrooms in higher education: International perspectives on equity and inclusion (pp. 97-109). Emerald Publishing. https://doi.
org/10.1108/S2055-364120190000016010

Kim, T. (2020). Diasporic comparative education: An initial tribute to anxiety and hope. Comparative Education, 56(1), 111-126. https://doi.org/10.1080/ 03050068.2020 .1714328

Krischler, M., Powell, J., \& Pit-Ten, I. M. (2019). What is meant by inclusion? On the effects of different definitions on attitudes toward inclusive education. European Journal of Special Needs Education, 34(5), 632-648. https://doi.org/10.1080/08856257. 2019.1580837

Lawrie, G., Marquis, E., Fuller, E., Newman, T., Qiu, M., Nomikoudis, M., Roelofs, F., \& van Dam, L. (2017). Moving towards inclusive learning and teaching: A synthesis of recent literature. Teaching \& Learning Inquiry, 5(1), 1-13. http://dx.doi.org/10.20343/ teachlearninqu.5.1.3

Lingard, B., Martino, W., \& Rezai, G. (2013). Testing regimes, accountabilities and education policy: Commensurate global and national developments. Journal of Education Policy, 28(5), 539-556.

Maringe, F., \& Sing, N. (2014). Teaching large classes in an increasingly internationalising higher education environment: Pedagogical, quality and equity issues. Higher Education, 67(6), 761-782. http://dx.doi.org/ 10.1007/s10734-013-9710-0

Martínez-Usarralde, M. J. (2021). Inclusión educativa comparada en UNESCO y OCDE desde la cartografía social [Comparative educational inclusion in UNESCO and OECD from social cartography]. Educación XX1, 24(1), 93-115. http://dx.doi.org/10.5944/educXX1. 26444

Martins, M. H., Borges, M. L., \& Gonçalves, T. (2018). Attitudes towards inclusion in higher education in a Portuguese university. International Journal of Inclusive Education, 22(5), 527-542. http://dx.doi.org/ 10.1080/13603116.2017.1377299

Matthews, K. E., Dwyer, A., Russell, S., \& Enright, E. (2019). It is a complicated thing: Leaders' conceptions of students as partners in the neoliberal university. Studies in Higher Education, 44(12), 2196-2207. https://doi.org/10.1080/03075079.2018.1482268

Melero, N., Moriña, A., \& Lopez-Aguilar, R. (2018). In life-lines of Spanish students with disabilities during their university trajectory. Qualitative Report, 23(5), 1127-1145.

Melero, N., Moriña, A., \& Perera, V. (2019). Faculty actions for an inclusive practice at the university. Revista Brasileira de Educaçao, 24(1), 1-19. http:// dx.doi.org/10.1590/s1413-24782019240016

Meyer, H. D., \& Powell, J. W. (2020). New institutionalism in higher education. In M. E. David \& M. J. Amey (Eds.), The SAGE encyclopedia of higher education (pp. 1084-1089). SAGE. https://doi.org/4135/ 9781529714395.n405

Moberg, E. M., Korenaga, K., Kuorelahti, M., \& Savolainen, H. (2020). Struggling for inclusive education in Japan and Finland: Teachers' attitudes 
towards inclusive education. European Journal of Special Needs Education, 35(1), 100-114. http://dx. doi.org/10.1080/08856257.2019.1615800

Moliner, O., Arnaiz, P., \& Sanahuja, A. (2020). Bridging the gap between theory and practice: What strategies do university faculty use to mobilize knowledge about inclusive education? Educación XX1, 23(1), 173-195. https://doi.org/10.5944/educXX1.23753

Morgado, B., Lopez-Gavira, R., \& Moriña, A. (2017). The ideal university classroom: Stories by students with disabilities. International Journal of Educational Research, 85, 148-156. https://doi.org/10.1016/j. ijer.2017.07.013

Moriña, A. (2017). Inclusive education in higher education: Challenges and opportunities. European Journal of Special Needs Education, 32(1), 3-17. https:// doi.org/10.1080/08856257.2016.1254964

Moriña, A., \& Carballo, R. (2017). The impact of a faculty training program on inclusive education and disability. Evaluation and Program Planning, 65, 77-83. http://dx.doi.org/10.1016/j.evalprogplan. 2017.06.004

NERCHE. (2016). Self-assessment rubric for the institutionalization of diversity, equity and inclusion in higher education. https://tinyurl.com/y4xozu8s

Nind, M., \& Lewthwaite, S. (2018). Hard to teach: Inclusive pedagogy in social science research methods education. International Journal of Inclusive Education, 22(1), 74-88. http://dx.doi.org/10.1080/ 13603116.2017.1355413

Nóvoa, A. (2018). Comparing Southern Europe: The difference, the public, and the common. Comparative Education, 54(4), 548-561. http://dx.doi.org/ 10.1080/03050068.2018.1528781

Orozco, I., \& Moriña, A. (2020). Spanish faculty members speak out: Barriers and aids for students with disabilities at university. Disability \& Society, 36(12). http://dx.doi.org/10.1080/09687599.2020.1723495

Powell, J. J. (2020). Comparative education in an age of competition and collaboration. Comparative Education, 56(1), 57-78. http://dx.doi.org/10.1080/ 03050068.2019 .170124

Ramia, N., \& Díaz, K. (2019). Service-learning as a methodology to promote equity and inclusion: Best practice experience in Ecuador. In J. Hoffman, J. Blessinger, \& M. Makhanya (Eds.), Strategies for fostering inclusive classrooms in higher education: International perspectives on equity and inclusion (pp. 53-66). Emerald Publishing. https://doi.org/ 10.1108/S2055-364120190000016013

Ramos, G., Pérez, A., Chiva, I., \& Moral, A. (2021). Validation of a scale of attention to diversity for university teachers. Educación XX1, 24(2). https://doi.org/ 10.5944/educXX1.28518

Rubio, V. (2017). Inclusion of people with disabilities in higher education from a social responsibility approach, within a discourse transitions context related to the integration/inclusion binomio.
Revista Latinoamericana de Educación Inclusiva, 11(2), 199-216.

Ryder, A. J., Reason, R. D., Mitchell, J. J., Gillon, K., \& Hemer, K. M. (2016). Climate for learning and students' openness to diversity and challenge: A critical role for faculty. Journal of Diversity in Higher Education, 9(4), 339-352. http://dx.doi.org/10.1037/ a0039766

Sanahuja, A., Benet, A., \& Nieto, R. (2020). Training on inclusion in higher education: Prepared to work within the inclusive model? Culture and Education, 32(1), 78-105. http://dx.doi.org/10.1080/11356405. 2019.1705595

Schuelka, M. J., \& Lapham, K. (2018). Comparative and international inclusive education: Trends, dilemmas, and future directions. In A. W. Wiseman (Ed.), Annual review of comparative and international education (pp. 35-42). Emerald Publishing. https://doi.org/ 10.1108/S1479-367920190000037003

Sengupta, E., Blessinger, P., Hoffman, J., \& Makhanya, M. (2019). Introduction to strategies for fostering inclusive campuses in higher education. In J. Hoffman, J. Blessinger, \& M. Makhanya (Eds.), Strategies for facilitating inclusive campuses in higher education: International perspectives on equity and inclusion (innovations in higher education teaching and learning) (pp. 3-14). Emerald Publishing. https://doi.org/10.1108/ S2055-364120190000017001

Sharma, U., \& Mullick, J. (2020). Bridging the gaps between theory and practice of inclusive teacher education. Oxford Research Encyclopedias. http:// dx.doi.org/10.1093/acrefore/9780190264093.013. 1226

Stentiford, L., \& Koutsouris, G. (2020). What are inclusive pedagogies in higher education? A systematic scoping review. Studies in Higher Education. Advance online publication. http://dx.doi.org/ 10.1080/03075079.2020.1716322

Symaco, L. P., \& Tee, M. Y. (2018). Social responsibility and engagement in higher education: Case of the ASEAN. International Journal of Educational Development, 66, 184-192. https://doi.org/10.1016/ j.ijedudev.2018.10.001

Thomsen, B., Muurlink, O., Best, T., Thomsen, J., \& Copeland, K. (2020). Transcultural development. Human Organization, 79(1), 43-56. http://dx.doi. org/10.17730/0018-7259.79.1.43

Tzavara, D., \& Wilczek, B. (2019). Online: A new 'geography' of learning that supports female access to higher education. In J. Hoffman, J. Blessinger, \& M. Makhanya (Eds.), Strategies for fostering inclusive classrooms in higher education: International perspectives on equity and inclusion (pp. 213-231). Emerald Publishing. https://doi.org/10.1108/S2055364120190000016016

van Vught, F. A., van der Wende, M. C., \& Westerheijden, D. F. (2018). Globalisation and differentiation in higher education systems. In J. Huisman \& M. 
Tght (Eds.), Theory and method in higher education research (pp. 85-101). Emerald Publishing. https:// doi.org/10.1108/S2055-3641201900000160179

Walker, M. (2020). Failures and possibilities of epistemic justice, with some implications for higher education. Critical Studies in Education, 61(3), 263-278. https:// doi.org/10.1080/17508487.2018.1474774

Whitburn, B., Moss, J., \& O'Mara, J. (2017). Inclusive education, subjectivities and the posts. In V. Plows \& B. Whitburn (Eds.), Inclusive education: Making sense of everyday practice (pp. 31-44). SensePublishers. https://doi.org/10.1007/978-94-6300-866-2_2

Wise, G., Dickinson, C., Katan, K., \& Gallegos, M. C.
(2020). Inclusive higher education governance: Managing stakeholders, strategy, structure and function. Studies in Higher Education, 45(2), 339-352. http:// dx.doi.org/10.1080/03075079.2018.1525698

Wood, P., \& Smith, J. (2018). Research in education basic concepts and methodology to develop research projects. Narcea.

Zapp, M., \& Ramirez, F. O. (2019). Beyond internation)alisation and isomorphism: The construction of a global higher education regime. Comparative Education, 55(4), 473-493. https://doi.org/10.1080/ 03050068.2019.163810

\section{About the Authors}

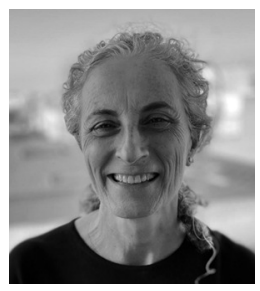

Amparo Pérez-Carbonell is Professor of Research Methods and Diagnosis in Education at the Faculty of Philosophy and Educational Sciences of the University of Valencia (Spain) since 1988. Her research focuses on topics specific to the research group "Diversity and Evaluation in Lifelong Learning" (DIVFOREVA), which she has been part of since its creation. These topics include diversity and educational responsibility, gender equality, educational mediation, evaluation and teaching innovation methodologies. She is a member of research associations such as AIDIPE, EERA, AVOP and AMIT. ORCID: https://orcid.org/0000-0002-3537-0293

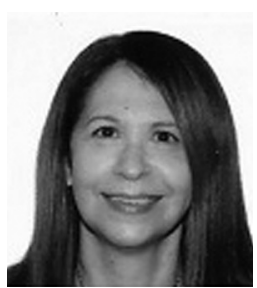

Genoveva Ramos-Santana is Professor of the Department of Research and Diagnostic Methods at Education from the University of Valencia (Spain). Her research addresses the design and validation of measurement scales and gender equality projects. She is co-director of the "Own Master's Degree in Attention to Diversity" at the University of Valencia since 2015. She belongs to the research group "Diversity and Evaluation in Lifelong Learning" (DIVFOREVA). She is a member of research associations such as AMIT and AIDIPE. ORCID: https://orcid.org/0000-0002-6931-8725

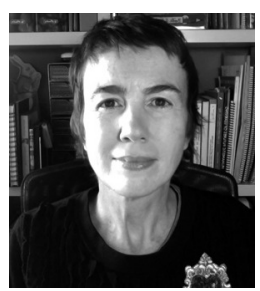

María-Jesús Martínez-Usarralde is Professor of Comparative and International Education at the University of Valencia (Spain). From 2009 to 2011 she was Vice Dean of Innovation and Educational Quality at Faculty of Education. From 2015 to 2018 she was the Director of the Training Center Manuel Sanchis Guarner of the University of Valencia, where she was responsible for the policies of university teacher training and educational innovation of the institution. She is member of DIVFOREVA. ORCID: https://orcid.org/0000-0001-6777-3399 